University of Nebraska - Lincoln

DigitalCommons@University of Nebraska - Lincoln

Sociology Department, Faculty Publications

Sociology, Department of

$5-2012$

\title{
Interactive Effects of Church Attendance and Religious Tradition on Depressive Symptoms and Positive Affect
}

\author{
Philip Schwadel \\ University of Nebraska-Lincoln, pschwadel2@unl.edu \\ Christina D. Falci \\ University of Nebraska-Lincoln, cfalci2@unl.edu
}

Follow this and additional works at: https://digitalcommons.unl.edu/sociologyfacpub

Part of the Sociology Commons

Schwadel, Philip and Falci, Christina D., "Interactive Effects of Church Attendance and Religious Tradition on Depressive Symptoms and Positive Affect" (2012). Sociology Department, Faculty Publications. 171. https://digitalcommons.unl.edu/sociologyfacpub/171

This Article is brought to you for free and open access by the Sociology, Department of at DigitalCommons@University of Nebraska - Lincoln. It has been accepted for inclusion in Sociology Department, Faculty Publications by an authorized administrator of DigitalCommons@University of Nebraska - Lincoln. 
Published in Society and Mental Health 2:1 (2012), pp. 21-34; DOI: 10.1177/2156869312442885

Copyright $\odot 2012$ American Sociological Association; published by Sage Publications. Used by permission.

http://smh.sagepub.com

\title{
Interactive Effects of Church Attendance and Religious Tradition on Depressive Symptoms and Positive Affect
}

\author{
Philip Schwadel and Christina D. Falci \\ University of Nebraska-Lincoln, Lincoln, NE, USA \\ Corresponding author - Philip Schwadel, University of Nebraska-Lincoln, \\ 711 Oldfather Hall, Lincoln, NE 68588-0324, USA; email pschwadel2@unl.edu
}

\begin{abstract}
Using a survey of adults in Nebraska, we find that the association between church attendance and mental health varies across religious traditions and across two distinct dimensions of mental health-depressive symptoms and positive affect. Specifically, the association between church attendance and depressive symptoms differs for mainline Protestants, evangelical Protestants, and Catholics. Of these three religious traditions, only mainline Protestants report significantly lower levels of depressive symptoms when they attend church more often. Comparing across religious traditions, we find that among high attendees, evangelical Protestants report considerably more depressive symptoms than do Catholics; among low attendees, evangelicals report fewer depressive symptoms than do mainline Protestants. The results also show that church attendance is unrelated to positive affect for respondents as a whole and across the three religious traditions. We discuss how these differences in the relationship between church attendance and mental health comport with theological and social distinctions across religious traditions.
\end{abstract}

Keywords: depression, mental health, religion

\section{INTRODUCTION}

Empirical research on the effects of religious participation on mental health has produced inconsistent findings (Hackney and Sanders 2003; Koenig 2009; Koenig, McCullough, and Larson 2001). While the majority of research finds that religious participation moderately bolsters mental health (e.g., Ellison et al. 2001; Schieman 2008), other research reports no correlation between religious participation and mental health (e.g., Ellison 1991; Vaillant et al. 2008). In some cases, analyses even show a negative effect of religious participation on mental health (e.g., Dalgalarrondo et al. 2008; King and Schafer 1992) or find a curvilinear relationship (e.g., Tabak and Mickelson 2009). The effect of religious participation on mental health may depend on the institutional context because churches vary in the extent to which they promote both the social and cognitive resources that benefit mental health. Therefore, the inconsistent findings of past research may partially result from the failure to account for variation in the effect of religious participation on mental health across religious traditions.

Moreover, the potential beneficial and/or detrimental effects of religious participation on mental health may not be fully revealed without separately analyzing positive and negative dimensions 
of mental health. Recent research suggests that positive dimensions of mental health, such as hope and happiness, often have different causes from negative dimensions of mental health, such as depression and anxiety (e.g., Huppert 2009). The association between religion and mental health, in particular, may differ for positive and negative dimensions of mental health (Pearce and Koenig 2010). Expanding on these lines of inquiry, we propose that the theological and social conditions across Christian religious traditions differentially impact positive and negative dimensions of mental health.

Using data from the Nebraska Annual Social Indicators Survey, the purpose of this research is to explore the interactive effects of church attendance and Christian religious traditions on two subscales of the Center for Epidemiological Studies' Depression Scale (CES-D), one representing positive affect and the other depressive symptoms. We advance previous research by examining the tradition-specific association between church attendance and two distinct dimensions of mental health.

\section{RELIGIOUS PARTICIPATION AND MENTAL HEALTH}

Religious participation may provide numerous forms of social resources, such as social support and social integration (Durkheim [1915] 1965). Social support in churches often comes from strong connections with other churchgoers, or what the social capital research refers to as bonding capital (Smidt 2003). Congregants supply the emotional, spiritual, and physical support to one another that is associated with better mental health (Krause et al. 2001; Turner and Turner 1999). Much contemporary research attributes the positive association between religion and mental health to the high levels of social support or bonding capital in religious congregations (e.g., Lim and Putnam 2010; Nooney and Woodrum 2002; Pescosolido and Georgianna 1989).

An additional social resource is the ability of churches to help congregants make new connections across diverse social networks (Beyerlein and Hipp 2006; Williams 2003), what the social capital research refers to as bridging capital (Smidt 2003). Church attendance is associated with more diverse roles (i.e., friends, neighbors, voluntary association members, etc.) within an individual's personal network (McIntosh, Sykes, and Kubena 2002). Church members, in particular, are likely to report high levels of "status-bridging" capital (Wuthnow 2002). Like bonding capital, bridging capital can be beneficial to mental health (Ferlander 2007). For instance, bridging capital is associated with greater knowledge about health issues and lower levels of depression (Erickson 2003). In some communities, such as high-poverty neighborhoods, diverse networks may be more important than close emotional ties in promoting mental health (Mitchell and LaGory 2002).

Religious participation also provides cognitive benefits that may lead to better mental health. Religion helps people make sense of the world (Vilchinsky and Kravetz 2005). Some religious beliefs, which are generally reinforced through church participation, are associated with better mental health (Ellison, Burdette et al. 2009). For instance, belief in the afterlife and church attendance are both positively correlated with feelings of tranquility and negatively correlated with anxiety (Ellison, Burdette et al. 2009). Church attendance provides positive cognitive appraisals "by promoting a positive and coherent worldview," which can help people cope with stressful situations (Koenig et al. 2001:225). Coping resources are especially enhanced when religion imparts a greater sense of mastery and selfesteem (Ellison et al. 2001; Schieman 2008). Mastery and self-esteem are often reinforced through interpersonal support networks in churches, positive appraisals from other attendees, interaction with a perceived divine other, and active prayer (Ellison 1993, 1991; Ellison et al. 2001; Pollner 1989); and they are beneficial to mental health and reduce the negative effects of stress exposure (Pearlin et al. 1981). Overall, then, there is a clear theoretical argument linking the social and cognitive mechanisms promoted through church attendance to improved mental health (Koenig et al. 2001). Yet, it is unlikely that all religious traditions produce the same kind or level of social and cognitive resources.

\section{RELIGIOUS TRADITIONS}

The stress process perspective emphasizes that the prevalence of social and cognitive resources vary across status groups and social contexts (Pearlin 1989; Turner and Turner 1999). Similarly, there is variation across religious traditions in the promotion of social and cognitive resources. In particular, previous research suggests that the social and cognitive re- 
sources derived from church participation are quite different for evangelical Protestants than for mainline Protestants and Catholics.

Research on American religion emphasizes the high degree of social integration and support in evangelical Protestant churches. Evangelical Protestants' strong social ties are likely to come from other church attendees (Iannaccone 1988; Scheitle and Adamczyk 2009). Evangelical Protestants receive more bonding capital through church than do affiliates of other Christian traditions, especially Catholics (Ellison, Krause et al. 2009). The church-based social interactions among evangelical Protestants, however, may produce a very limited form of social capital because evangelical Protestants are less educated, have fewer verbal skills, and have lower incomes than do Catholics and mainline Protestants (Keister 2008; Pyle 2006; Sherkat 2010). Their churches also have less class and race diversity (Dougherty 2003; Schwadel 2009).

Consequently, although evangelical Protestants may have considerable access to bonding capital in their churches, the social networks they develop in church often have limited resources. This is especially problematic given that evangelical Protestants tend to have relatively few friends outside of their churches (Scheitle and Adamczyk 2009). In fact, Iannaccone (1988) argues that the social insularity of evangelical churches is their defining characteristic. Thus, both limitations in the social networks within evangelical churches and the lack of bridging capital outside of the church may diminish the ability of evangelical church attendance to promote mental health.

Evangelical Protestant churches may also compromise the development of cognitive resources. Some religious beliefs diminish cognitive resources, particularly mastery (Pollner 1989). Evangelical churches tend to emphasize the pervasiveness of sin, a wrathful and controlling God, and the premillennial belief that the world will degrade until Christ returns (Ammerman 1982; Marsden 1991). These beliefs focus on a lack of control and a sense of helplessness, which should compromise mastery and diminish a person's ability to cope with stress (Ellison and Burdette forthcoming; Ross and Sastry 1999). Since Catholics and mainline Protestants do not emphasize these religious beliefs, it is not surprising that they report higher levels of mastery than do evangelical Protestants (Braam et al. 1998; Ellison 1993; Schieman, Nguyen, and Elliott 2003).
In sum, potential differences in social and cognitive resources across Christian traditions could lead to a differential effect of church attendance on mental health for mainline Protestants, evangelical Protestants, and Catholics. In particular, evangelical Protestant churches provide limited social resources and theological messages that can reduce mastery. These drawbacks, however, may be more relevant for some mental health outcomes than for others.

\section{POSITIVE AND NEGATIVE DIMENSIONS OF MENTAL HEALTH}

Mental health refers to subjective states that are either pleasant or unpleasant with emotional and/ or physiological manifestations (definition adapted from Mirowsky and Ross 2003). Combining the mood and malaise aspects of two key unpleasant states (depression and anxiety) is what Mirowksy and Ross (2003) refer to as psychological distress. Pleasant states, such as psychological well-being, also have mood (e.g., happy) and malaise (e.g., energetic) components. Some scholars argue that psychological distress and well-being are two ends of the same continuum (e.g., Dohrenwend et al. 1980; Mirowsky and Ross 2003), whereas others suggest they are distinct concepts with potentially unique causes (e.g., Huppert 2009; Keyes, Schmotkin, and Ryff 2002).

In the current study, we take the latter approach and distinguish pleasant subjective states (or positive mental health outcomes) from unpleasant subjective states (or negative mental health outcomes). We do so because recent research supports the distinct concepts approach (e.g., Keyes 2005; Payton 2009; Ryff et al. 2006) and because the results from an exploratory and confirmatory factor analysis of the CESD on a sample of Nebraskan adults warrant such an approach. Moreover, recent research on religion and mental health argues that the impact of religious participation may vary across mental health outcomes (e.g., Hackney and Sanders 2003; Pearce and Koenig 2010). We take this last argument one step farther and also consider the possibility of tradition-specific effects of church attendance on different mental health outcomes.

Some scholars argue that behaviors are important predictors of positive dimensions of mental health or psychological well-being (e.g., Huppert 2009; Lyubomirsky, Sheldon, and Schkade 2005). Church atten- 
dance is positively associated with healthy lifestyle behaviors, such as preventive care, reduced alcohol consumption, and not smoking cigarettes (Hill et al. 2006). Evangelical Protestants may be particularly advantaged with regard to positive mental health outcomes due to their greater emphasis on healthy lifestyles relative to Catholics and mainline Protestants (George, Ellison, and Larson 2002; Koenig et al. 2001). Furthermore, evangelical churches place considerable importance on happiness and evangelicals sometimes use happiness as an indicator of group membership (Wilkins 2008). In sum, church attendance may promote psychological well-being across all religious traditions, and it may be especially beneficial for evangelical Protestants (Hackney and Sanders 2003; Pearce and Koenig 2010).

For negative dimensions of mental health, in contrast, we propose that church attendance may be unlikely to prevent the occurrence of psychological distress for some religious traditions. Drawing from stress process theory (Pearlin et al. 1981), social and cognitive resources should be important for preventing psychological distress. As reviewed previously, churchgoing evangelicals are exposed to potentially mastery-reducing theological messages and insular, resource-poor social networks. Relative to Catholics and mainline Protestants, evangelical Protestants lack the social connections that provide information on mental health issues and services that can help mitigate psychological distress (Erickson 2003). Therefore, attendance at evangelical churches may be unhelpful for preventing the occurrence of psychological distress.

At the same time, church attendance may actually be detrimental to the psychological distress of evangelical Protestants. Specifically, the theological messages evangelical Protestants are exposed to at church may increase their levels of psychological distress. Freud ([1927] 1964) argued that emphasizing the pervasiveness of sin produces anxiety, and recent empirical research supports this proposition (e.g., Ellison, Burdette et al. 2009). A sense of divine control is also associated with higher levels of psychological distress among low socioeconomic status (SES) whites (Schieman et al. 2006), and evangelical Protestants are disproportionately low SES whites (Keister 2008). Overall, then, the potentially mastery-reducing and anxiety-inducing theological messages combined with limited social networks may result in churchgoing evangelical Protestants being especially likely to report high levels of psy- chological distress relative to churchgoing Catholics and mainline Protestants.

\section{DATA AND METHOD}

We use data from the 2006 Nebraska Annual Social Indicators Survey (NASIS) to examine the joint impact of religious affiliation and church attendance on mental health. The 2006 NASIS is a telephone survey of 1,821 Nebraskans fielded between November 2006 and March 2007. Random digit dialing and random selection of household members produced a sample of noninstitutionalized Nebraskans at least 19 years of age. Of the dialed households, 33 percent participated in the survey (50 percent refusal rate). ${ }^{1}$ The NASIS sample is comparable to U.S. census data for Nebraska on most key demographic variables, such as income, education, and age. ${ }^{2}$ NASIS respondents, however, are more likely to be female, and they differ on race. White non-Hispanics comprise 82.1 percent of Nebraskans compared to 91.4 percent of the NASIS sample. This difference probably reflects the lack of children in the NASIS sample and that children born to immigrants are a fast growing group in Nebraska. All analyses employ a weight variable to adjust for nonresponse and variations from population means. Although the regional sample limits the generalizability of our research, the NASIS is the only survey we could locate that contains detailed measures of religious affiliation, church attendance, and both positive and negative dimensions of mental health. Nebraskans are relatively similar to U.S. citizens as a whole, though they are more likely to be non-Latino, white, and Lutheran and less likely to be foreign born and to speak a language other than English in their homes. ${ }^{3}$

\section{Dependent Variables}

The dependent variables are drawn from a 20item CES-D where respondents reported on the number of days in the past week that they had each symptom (see Table 1 for descriptive statistics). Although Radloff (1977) created the index to cover four mental health dimensions (depressed mood, positive mood, somatic complaints, and interpersonal problems), several factor structures have been proposed and tested (see Riddle, Blais, and Hess 
Table 1. Descriptive Statistics

\begin{tabular}{|c|c|c|c|c|}
\hline Focal Dependent & Mean & Standard deviation & Minimum & Maximum \\
\hline Depressive symptoms & 10.28 & 11.95 & 0 & 91 \\
\hline Positive affect & 3.93 & $5 \cdot 30$ & 0 & 28 \\
\hline \multicolumn{5}{|l|}{$\begin{array}{l}\text { Focal independent } \\
\text { Church attendance }\end{array}$} \\
\hline Low & .22 & & 0 & 1 \\
\hline Moderate & .25 & & o & 1 \\
\hline High & .53 & & 0 & 1 \\
\hline \multicolumn{5}{|l|}{ Religious tradition } \\
\hline Evangelical Protestant & .28 & & o & 1 \\
\hline Mainline Protestant & .40 & & o & 1 \\
\hline Catholic & .32 & & o & 1 \\
\hline \multicolumn{5}{|l|}{ Controls } \\
\hline Female & .62 & & 0 & 1 \\
\hline Physical health & 3.16 & .72 & 1 & 4 \\
\hline Income & 8.30 & 2.76 & 1 & 12 \\
\hline \multicolumn{5}{|l|}{ Education } \\
\hline High school or less & .33 & & o & 1 \\
\hline Some college & .30 & & 0 & 1 \\
\hline BA degree or higher & .37 & & o & 1 \\
\hline Non-white & .05 & & o & 1 \\
\hline Married & .67 & & o & 1 \\
\hline Children & .36 & & o & 1 \\
\hline Age & 52.00 & 16.17 & 19 & 94 \\
\hline Urban & .42 & & 0 & 1 \\
\hline
\end{tabular}

$N=1,245$.

2002). A three-factor model provided the best fit to our data (Goodness of Fit Index $=.9997$, root mean square error of approximation $=.0531$ ), which is not surprising given the high proportion of whites in our sample (Perreira et al. 2005). Two of these factors comprise the dependent variables in our study. Depressive symptoms contains seven mood (felt sad, lonely, fearful, or depressed; could not shake the blues; bothered by things; and life had been a failure) and seven malaise (trouble keeping your mind on what you were doing, everything you did was an effort, talked less than usual, poor appetite, restless sleep, crying spells, and could not get going) items primarily pertaining to depression. Positive affect contains four positive mood items (hopeful about the future, as good as others, feel happy, and enjoy life), which were reverse coded. ${ }^{4}$ For both depressive symptoms and positive affect, high values indicate poor mental health.

\section{Independent Variables}

Our primary independent variables measure religious tradition and church attendance. The religious tradition categories are coded according to the classification developed by Steensland and colleagues (2000). We delete Jewish, black Protestant, and "other" religion respondents from the analysis due to small number of cases (76 respondents). We also delete respondents who reported not having a religious affiliation because unaffiliated respondents were not asked about attending religious services (235 respondents). The religious tradition categories included in the final sample are evangelical Protestant, Catholic, and mainline Protestant. Since these groups are Christian traditions, we refer to the service attendance variable as church attendance. The church attendance measure has eight response options: never, less than once a year, once a year, several times a year, about once a month, nearly every week, once 
a week, and several times a week. This variable had a highly skewed distribution with over 50 percent of the cases falling within the highest two attendance categories. For this reason, we collapsed the attendance variable into three substantively meaningful categories. ${ }^{5}$ Low attendance indicates attending church several times a year or less often. Moderate attendance indicates attending church about once a month or nearly every week. High attendance indicates attending church every week or several times a week. High attendance is used as the reference category because it is the modal level of attendance reported by Nebraskans.

\section{Control Variables}

We control for characteristics related to both religious participation and mental health. Self-reported physical health is probably the most important control variable given the strong correlation between physical and mental health (Freemont and Bird 2000). Respondents were asked about their "overall health and well-being." Response choices included poor, fair, good, and excellent. Gender is dummy coded with a value of one indicating female respondents. Household income is measured with a 12-category variable ranging from less than $\$ 5,000$ to $\$ 100,000$ or more. Education is broken down into three categories: a high school degree or less, some college or a junior college degree, and a bachelor's or more advanced degree. We control for family formation with dummy variables for married respondents and those with children 18 or younger in the home. Race is measured with a variable indicating non-white respondents (5 percent of the final sample is nonwhite). Age is measured in years of age and centered around the mean to maintain a meaningful intercept in regression models. The urban variable denotes residence in one of the three counties that contain the cities of Omaha and Lincoln.

\section{Data Analysis Strategy}

Missing data on all control variables were imputed using the IVEware SAS module. Ten imputed data sets were created, and all regression analyses report the combined results of analyses on the imputed data sets using the Mianalyze procedure in SAS to obtain valid statistical inference. Our dependent variables are overdispersed count variables (see Table 1); therefore, we estimate all models using negative binomial regression (in SAS with the Genmod proce- dure). The significant dispersion parameters in our models signify the preference for negative binomial over Poisson (Erdman, Jackson, and Sinko 2008). Furthermore, comparing model fit statistics and the presence of a significantly negative inflated intercept parameter ruled out using a zero-inflated estimation strategy (Erdman et al. 2008). Finally, a regression diagnostic analysis revealed six influential outliers that were deleted from the sample.

The focal associations in our study pertain to significant differences in mental health outcomes across levels of church attendance both within and across religious traditions. To obtain all relevant group comparisons, two strategies were employed. First, since evangelical Protestants are the omitted reference group, the regression analyses identify significant differences in mental health across levels of church attendance among evangelical Protestants. To assess mental health differences across levels of church attendance for mainline Protestants and Catholics, we altered the omitted reference group for religious affiliation (analyses not shown). Second, within church attendance groups (e.g., among low attendees) significant differences across religious traditions were identified using custom hypothesis testing of the least square means (using the LSMESTIMATE statement in the Genmod procedure). The results of these analyses are reported in the following.

\section{RESULTS}

\section{Depressive Symptoms}

Table 2 reports results for depressive symptoms. Before addressing the focal associations, it is worth noting that women, those with worse self-reported physical health, the least educated, younger, and unmarried respondents report the most depressive symptoms (Model 1). Model 1 also shows that Catholics report significantly fewer depressive symptoms compared to evangelical Protestants $(b=-.152, p<$ $.05)$. Supplemental analysis, altering the omitted reference group, indicates that Catholics also report significantly fewer depressive symptoms than do mainline Protestants $(p<.05)$. There are no significant differences in depressive symptoms between mainline Protestants and evangelical Protestants. Finally, Model 1 shows that the overall association between church attendance and depressive symptoms is not significant $(b=.083, n s$ and $b=-.074, n s)$. The interactions in Model 2, however, tell quite a different story. 
Table 2. Negative Binomial Regressions for Depressive Symptoms on Church Attendance and Religious Tradition

\begin{tabular}{|c|c|c|c|c|}
\hline & \multicolumn{4}{|c|}{ Depressive symptoms } \\
\hline & \multicolumn{2}{|c|}{ Model 1} & \multicolumn{2}{|c|}{ Model 2} \\
\hline & $b$ & $S E$ & $b$ & $S E$ \\
\hline Intercept & 3.805 & .19 & 3.880 & .20 \\
\hline Mainline Protestant ${ }^{a}$ & .007 & .08 & -.072 & .10 \\
\hline Catholic $^{a}$ & $-.152 *$ & .08 & $-.246 *$ & .10 \\
\hline Low attendance ${ }^{b}$ & .083 & .08 & -.344 & .18 \\
\hline Moderate attendance ${ }^{b}$ & -.074 & .07 & -.128 & .13 \\
\hline \multicolumn{5}{|l|}{ Interaction terms } \\
\hline Low $\times$ mainline & & & $.511 *$ & .21 \\
\hline Moderate $\times$ mainline & & & .049 & .18 \\
\hline Low $\times$ Catholic & & & $.514^{*}$ & .22 \\
\hline Moderate × Catholic & & & .143 & .19 \\
\hline \multicolumn{5}{|l|}{ Controls } \\
\hline Female & $.225^{* * *}$ & .06 & $.231 * * *$ & .06 \\
\hline Physical health & $-.448 * * *$ & .04 & $-.447^{* * *}$ & .04 \\
\hline Income & -.022 & .01 & -.024 & .01 \\
\hline Some college $e^{c}$ & .109 & .08 & .113 & .08 \\
\hline High school or less ${ }^{c}$ & $.306 * * *$ & .08 & $.301 * * *$ & .08 \\
\hline Non-white & .216 & .12 & .217 & .12 \\
\hline Married & $-.410 * * *$ & .07 & $-.408 * * *$ & .07 \\
\hline Children & -.005 & .07 & -.009 & .07 \\
\hline Age (centered) & $-.011 * * *$ & .00 & $-.010 * * *$ & .00 \\
\hline Urban & .075 & .06 & .059 & .06 \\
\hline Dispersion & $.924 * * *$ & .04 & $.918 * * *$ & .04 \\
\hline
\end{tabular}

$\mathrm{N}=1,245$

a. Evangelical Protestant is the omitted reference group.

b. High church attendance is the omitted reference group.

c. Bachelor's degree or higher is the omitted reference group.

$* p<.05 ; * * p<.01 ; * * * p<.001$ (two-tailed test)

Specifically, the association between church attendance and depressive symptoms varies across religious traditions.

Figure 1 illustrates these significant interaction effects. Importantly, there are group mean differences in depressive symptoms across levels of church attendance, both within and across religious traditions. Since evangelical Protestants are the omitted reference group, the church attendance coefficients in Model 2 represent the association between church attendance and depressive symptoms for evangelical Protestants. Although these coefficients do not reach conventional levels of statistical significance $(p<.05)$, it is important to note that the direction of the association between church attendance and depressive symptoms is positive among evangelical Protestants.
In other words, higher levels of church attendance tend to correspond with higher levels of depressive symptoms (low attendee mean $=7.1$, moderate attendee mean $=8.8$, high attendee mean $=10.0$ ). Moreover, the difference in depressive symptoms among high-attending and low-attending evangelical Protestants is significant at the $p<.10$ level $(b=-.344)$. The inability to reach the more conventional $p<.05$ level is probably due to low statistical power resulting from the relatively small number of low-attending evangelical Protestants in our sample $(n=38)$.

Among mainline Protestants and Catholics, in contrast, there is no evidence of a positive association between church attendance and depressive symptoms. Among mainline Protestants, low attendees $($ mean $=11.0)$ report significantly higher depressive 


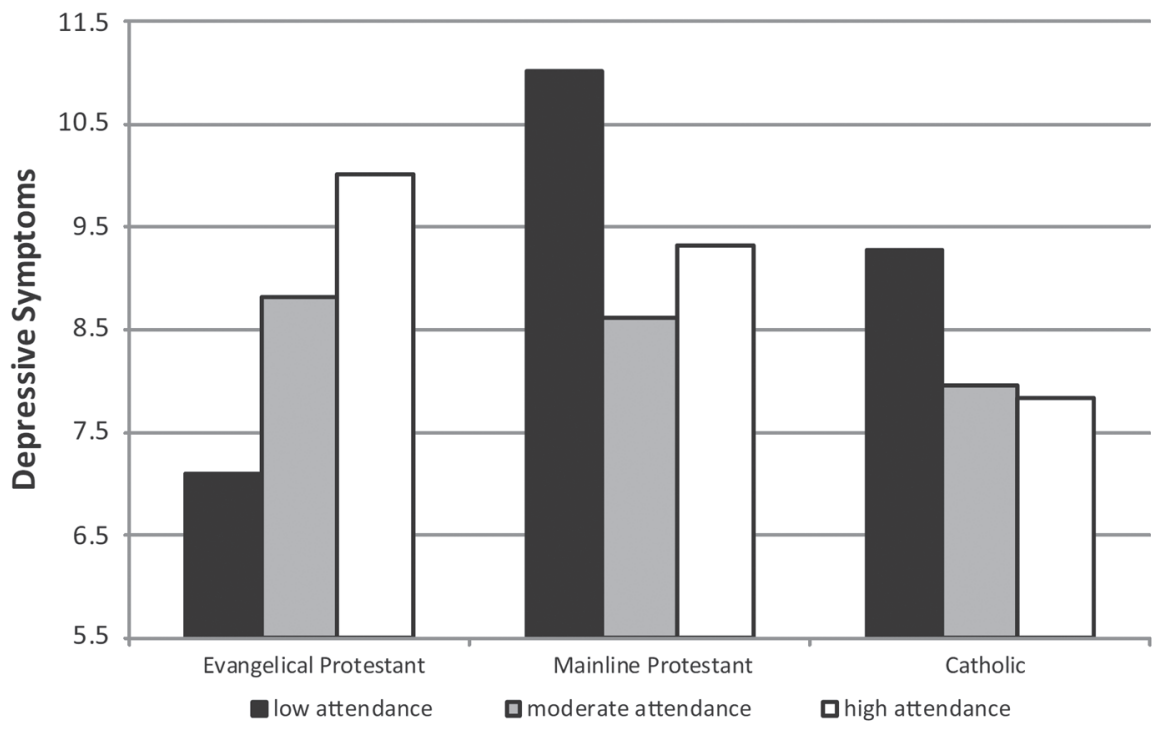

Figure 1. Depressive Symptoms across Religious Tradition and Church Attendance. The height of the chart represents two-thirds a standard deviation for depressive symptoms. The graphical results are based on the regression analysis show in Table 2, Model $2(N=1,245)$.

symptoms than do moderate attendees $($ mean $=8.6$, $p<.05)$, and high attendees have levels of depressive symptoms (mean $=9.3$ ) comparable to moderate attendees. Catholics manifest a pattern similar to mainline Protestants, with low attendees having the highest mean depressive symptoms (low attendee mean $=9.3$, moderate attendee mean $=8.0$, high attendee mean $=7.8$ ), but these group mean differences among Catholics are not statistically significant.

Across religious traditions, we find significant group mean differences in depressive symptoms by attendance levels. Among low attendees, evangelical Protestants report significantly lower levels of depressive symptoms $($ mean $=7.1)$ than do mainline Protestants $($ mean $=11.0, p<.05)$. Among high attendees, evangelical Protestants report significantly higher levels of depressive symptoms $($ mean $=10.0)$ than do Catholics (mean $=7.8, p<.05$ ). Overall, we find evidence that church attendance is more beneficial (or less harmful) to the depressive symptoms of mainline Protestants and Catholics than to evangelical Protestants.

\section{Positive Affect}

Table 3 reports results for positive affect. Positive affect is reverse coded, so high values indicate poor mental health. In contrast to depressive symptoms, Model 1 reports no significant associations between religious tradition and positive affect (Mainline $b=.020, n s$ and Catholic $b=-.075, n s$ ). Similar to the depressive symptoms results, Model 1 in Table 3 shows no significant association between church attendance and positive affect $(b=.035, n s$ and $b=.017$, $n s)$. Only two of the independent variables in Model 1 are meaningfully associated with positive affect. Specifically, the results in Model 1 show that women and older Nebraskans report relatively high levels of positive affect. More importantly, the positive affect results differ from the depressive symptoms results in that there are no significant interactions between religious tradition and church attendance (Model 2). Overall, the results in Table 3 suggest that church attendance is unrelated to positive affect among Nebraskans as a whole and among affiliates of the three major religious traditions.

\section{DISCUSSION AND CONCLUSIONS}

The results reported in Tables 2 and 3 and illustrated in Figure 1 show that the association between church attendance and mental health varies considerably across religious traditions and across indicators 
Table 3. Negative Binomial Regressions for Positive Affect on Church Attendance and Religious Tradition

\begin{tabular}{|c|c|c|c|c|}
\hline & \multicolumn{4}{|c|}{ Positive affect (reverse coded) } \\
\hline & \multicolumn{2}{|c|}{ Model 1} & \multicolumn{2}{|c|}{ Model 2} \\
\hline & $b$ & SE & $b$ & SE \\
\hline Intercept & $3.272 * * *$ & .29 & $3.172 * * *$ & .30 \\
\hline Mainline Protestant ${ }^{a}$ & .020 & .11 & .203 & .16 \\
\hline Catholic $^{a}$ & -.075 & .11 & .041 & .15 \\
\hline Low attendance ${ }^{b}$ & .035 & .12 & .141 & .27 \\
\hline Moderate attendance ${ }^{b}$ & .017 & .11 & .330 & .20 \\
\hline \multicolumn{5}{|l|}{ Interaction terms } \\
\hline Low $\times$ mainline & & & -.211 & .32 \\
\hline Moderate $\times$ mainline & & & -.502 & .26 \\
\hline Low $\times$ Catholic & & & -.123 & .32 \\
\hline Moderate $\times$ Catholic & & & -.410 & .28 \\
\hline \multicolumn{5}{|l|}{ Controls } \\
\hline Female & $-.029 * * *$ & .09 & $-.017^{* * *}$ & .09 \\
\hline Physical health & -.541 & .07 & -.543 & .07 \\
\hline Income & -.028 & .02 & -.028 & .02 \\
\hline Some college ${ }^{c}$ & -.152 & .12 & -.137 & .12 \\
\hline High school or less ${ }^{c}$ & .159 & .12 & .159 & .12 \\
\hline Non-white & -.166 & .19 & -.149 & .19 \\
\hline Married & -.179 & .11 & -.175 & .11 \\
\hline Children & .071 & .11 & .063 & .11 \\
\hline Age (centered) & $-.013 * * *$ & .00 & $-.013 * * *$ & .00 \\
\hline Urban & .113 & .10 & .123 & .10 \\
\hline Dispersion & $2.088 * * *$ & .12 & $2.076 * * *$ & .12 \\
\hline
\end{tabular}

$\mathrm{N}=1,245$

a. Evangelical Protestant is the omitted reference group.

b. High church attendance is the omitted reference group.

c. Bachelor's degree or higher is the omitted reference group.

$* p<.05 ; * * p<.01 ; * * * p<.001$ (two-tailed test)

of mental health. ${ }^{6}$ Among Nebraskans as a whole, church attendance appears to have little relationship with mental health - both depressive symptoms and positive affect. This, however, is not the case when we take differences across religious traditions into account. Low levels of church attendance are associated with more depressive symptoms for mainline Protestants, but not for evangelical Protestants or Catholics. Comparing across religious traditions, we find that among regular attendees, evangelical Protestants are especially likely to report depressive symptoms, and among irregular attendees, evangelical Protestants report relatively low levels of depressive symptoms. At the same time, there is no significant association between church attendance and positive affect. ${ }^{7}$ These results show the importance of treating posi- tive and negative dimensions of mental health as distinct outcomes, and they add to the literature on religion and mental health by demonstrating the contextual nature of the relationship between church attendance and negative dimensions of mental health.

An important implication of this research is that religious affiliation matters. Simply measuring church attendance without taking the context of this attendance into account misses a large part of the picture. Theoretical approaches to how religion may promote or retard mental health must not ignore the fact that religion is a social phenomenon (White 1968) that is socially enacted and produced (Durkheim [1915] 1965). The practice of religion and the social, cultural, and theological messages of religion vary across religious groups, aggregated into reli- 
gious traditions. Consequently, the ways in which religion influences mental health vary across religious traditions, and this variation may be responsible for inconsistent findings in previous research on church attendance and mental health. Differences in the impact of religious practices on mental health would likely be even greater if we could examine more proximate religious contexts. Future research can explore this proposition by examining how the congregational context influences mental health outcomes.

In addition to differences across religious traditions, our analysis highlights the importance of distinguishing among dimensions of mental health when focusing on religion. Recent empirical research suggests that psychological distress and well-being belong on their own continuums, rather than being opposite poles of the same continuum (e.g., Keyes 2005; Payton 2009; Ryff et al. 2006). Our results support employing distinct measures for psychological distress and well-being when studying religion and mental health. The failure to account for differences across domains of mental health can lead to results that misrepresent the impact of religion on mental health. Mental health scholars, who focus on stress exposure, have long known that multiple mental health measures are necessary to properly gauge differences across social statuses due to the nonspecific response to stress (e.g., Aneshensel 2005). Similarly, affiliates of different religious traditions may experience and define psychological distress and well-being in distinct ways (Wilkins 2008).

There are, of course, limitations to our analysis. Most notably, the sample is restricted to adults in Nebraska. The relationships we identified may differ across regions and may not be generalizable to the United States as a whole. The sample is also mostly white, which limits generalizability across racial and ethnic groups. Additionally, while we focused on church attendance, the association between religion and mental health may vary across indicators of religion, and church attendance may be acting as a proxy for other forms of congregational participation. Religious beliefs, perceptions, personal devotions, and more intensive forms of congregational activity may have distinct associations with mental health (Greenfield, Vaillant, and Marks 2009; Schieman 2008), which may differ across religious traditions. As with most research based on a cross-sectional survey, there is also the question of causation. It is quite possible that mental health impacts church attendance. Moreover, our analysis cannot specify the mechanisms that motivate the tradition-specific associations between church attendance and negative domains of mental health. While we suggest that theological messages and limited social networks in evangelical churches may explain the relatively high levels of depressive symptoms among regularly attending evangelical Protestants, this cannot be verified with the NASIS data. Finally, the size of our sample limited our ability to explore any additional moderating variables for the association between church attendance and mental health. Specifically, previous research suggests that the association between religious participation and mental health may differ for men and women (e.g., Maselko and Kubzansky 2006; McFarland 2010; Vallaint et al. 2008).

As with many sociological questions, addressing these research questions will require both quantitative and qualitative data. We must observe what happens in churches as well as how religious factors influence mental health among large samples of individuals and churches. It is clear, though, that we cannot assume that the effects of religion on mental health operate in similar ways among disparate religious and social groups or that religion always promotes positive mental health outcomes. We conclude by emphasizing that neither religion nor mental health are monolithic constructs - the association between religious participation and mental health differs across religious contexts and indicators of mental health.

\section{NOTES}

1. Response rate based on AAPOR Response Rate 3 (RR3). The response rate is not uncommonly low for contemporary social scientific research (e.g., Edgell, Gerteis, and Hartman 2006; Woolever and Bruce 2002).

2. All Nebraska census information retrieved from http://quickfacts.census.gov/qfd/states/31000.html on October 18, 2011.

3. Demographic comparisons between Nebraskans and U.S. citizens based on U.S. census information retrieved from http://quickfacts.census.gov/qfd/ states/31000.html on October 18, 2011. Religious affiliation information based on 2000 Religious Congregations and Membership in the United States study, as reported by the Association of Religion Data Archives (www.theARDA.com).

4. The positive affect indicators are reverse coded for two reasons. First, reverse coding results in larger values indicating poorer mental health for both de- 
pendent variables. Second, and more important, reverse coding results in a distribution suitable for the negative binomial regression models employed in the analysis.

5. We explored alternative coding for the church attendance variable (e.g., Presser and Chaves 2007; Schwadel 2010) and conducted sensitivity analyses with alternative codings and the original continuous measure of church attendance. The key findings reported in this article remain the same when we employ different coding schemes for the church attendance variable.

6. We located two previous studies that examine differences across religious traditions in the association between religious participation and mental health. Ellison and colleagues (2001) examined the interactive effects of religious participation and affiliation on depression, but they found only a small interaction between Catholic affiliation and attendance. We suggest several possible reasons for the differences between their findings and our results. Most importantly, as Ellison and his coauthors acknowledged, their data contain only broad denominational categories (e.g., Lutheran, Baptist, etc.), which fail to capture key distinctions. For instance, in the NASIS sample Lutherans are about evenly split between affiliates of the Evangelical Lutheran Church in America (mainline Protestant) and the Lutheran ChurchMissouri Synod (evangelical Protestant). Ellison and colleagues also use unaffiliated respondents as their reference category, which does not allow for comparisons across Christian traditions. Finally, it is possible that the interactive effects of religious tradition and church attendance vary by region since Ellison and his coauthors use data from Michigan and we use data from Nebraska. Similarly, Maselko and Kubzansky (2006) compared the effects of religious activity on psychological distress and happiness across religious traditions. Their findings differ from ours in regards to psychological distress. Importantly, they employ an index of religious participation while we focus on church attendance, they do not examine interactions but instead present separate models for each religious tradition, and their measure of psychological distress differs from ours.

7. Additional analyses (not shown) suggest that church attendance is beneficial to the positive affect of evangelical Protestant men, but it is not associated with positive affect for evangelical Protestant women. This comports with empirical research on gender differences in the association between religion and mental health (e.g., Maselko and Kubzansky 2006; McFarland 2010). We do not present these gender- and tradition-specific results because the three-way interaction (attendance $\times$ religious tradition $\times$ gender) term was only significant at the $p<.10$ level.

\section{REFERENCES}

Ammerman, Nancy T. 1982. “Operationalizing Evangelicalism: An Amendment." Sociological Analysis 43:170-71.

Aneshensel, Carol S. 2005. "Research in Mental Health: Social Etiology versus Social Consequences." Journal of Health and Social Behavior 46:221-28.

Beyerlein, Kraig and John R. Hipp. 2006. “From Pews to Participation: The Effects of Congregation Activity and Context on Bridging Civic Engagement." Social Problems 53:97-117.

Braam, Arjan W., Aartjan T. F. Beekman, Cees P. M. Knipscheer, Dorly J. H. Deeg, Pieter Van Eeden, and Willem Van Tilburg. 1998. "Religious Denomination and Depression in Older Dutch Citizens: Patterns and Models." Journal of Aging and Health 10:483-503.

Dalgalarrondo, Paulo, Leticia Marín-León, Neury José Botega, Marilisa Berti De Azevedo Barros, and Helenice Bosco De Oliveira. 2008. "Religious Affiliation and Psychiatric Morbidity in Brazil: Higher Rates among Evangelicals and Spiritists." International Journal of Social Psychiatry 54:562-74.

Dohrenwend, Bruce P., Barbara Dohrenwend, Madelyn Gould, Bruce Link, Richard Neugenbauer, and Robin Wunsch-Hitzig. 1980. Mental Illness in the United States: Epidemiological Estimates. New York: Praeger.

Dougherty, Kevin D. 2003. "How Monochromatic is Church Membership? Racial-ethnic Diversity in Religious Communities." Sociology of Religion 64: 65-85.

Durkheim, Emile. [1915] 1965. The Elementary Forms of the Religious Life. New York: The Free Press.

Edgell, Penny, Joseph Gerteis, and Douglas Hartman. 2006. "Atheists as 'Other': Moral Boundaries and Cultural Membership in American Society." American Sociological Review 71:211-34.

Ellison, Christopher G. 1991. "Religious Involvement and Subjective Well-being." Journal of Health and Social Behavior 32:80-99.

Ellison, Christopher G. 1993. "Religious Involvement and Self-perception among Black Americans." Social Forces 71:1027-55.

Ellison, Christopher G., Jason D. Boardman, David R. Williams, and James S. Jackson. 2001. "Religious Involvement, Stress, and Mental Health: Findings from the 1995 Detroit Area Study." Social Forces 80:215-49.

Ellison, Christopher G. and Amy M. Burdette. Forthcoming. "Religion and the Sense of Control among U.S. Adults." Sociology of Religion.

Ellison, Christopher G., Amy M. Burdette, and Terrence D. Hill. 2009. “Blessed Assurance: Religion, Anxiety, 
and Tranquility among U.S. Adults." Social Science Research 38:656-67.

Ellison, Christopher G., Neal M. Krause, Bryan C. Shepherd, and Mark A. Chaves. 2009. "Size, Conflict, and Opportunities for Interaction: Congregational Effects on Members' Anticipated Support and Negative Interaction." Journal for the Scientific Study of Religion 48:1-15.

Erdman, Donald, Laura Jackson, and Arthur Sinko. 2008. "Zero-inflated Poisson and Zero-inflated Negative Binomial Models Using the COUNTREG Procedure." Paper 322-2008, The SAS Institute Inc., Cary, NC.

Erickson, Bonnie. 2003. "Social Networks: The Value of Variety." Contexts 2:25-31.

Ferlander, Sara. 2007. "The Importance of Different Forms of Social Capital for Health." Acta Sociologica 50:115-28.

Fremont, Allen M. and Chloe E. Bird. 2000. "Social and Psychological Factors, Physiological Processes, and Physical Health." Pp. 334-52 in Handbook of Medical Sociology, edited by C. E. Bird, P. Conrad, and A. M. Fremont. Upper Saddle River, NJ: Prentice Hall.

Freud, Sigmund. [1927] 1964. The Future of an Illusion. Garden City, NY: Doubleday.

George, Linda K., Christopher G. Ellison, and David B. Larson. 2002. "Explaining the Relationships between Religious Involvement and Health." Psychological Inquiry 13:190-200.

Greenfield, Emily A., George E. Vaillant, and Nadine F. Marks. 2009. "Do Formal Religious Participation and Spiritual Perceptions Have Independent Linkages with Diverse Dimensions of Psychological Well-being?" Journal of Health and Social Behavior 50:196-212. Hackney, Charles H. and Glenn S. Sanders. 2003. "Religiosity and Mental Health: A Meta-analysis of Recent Studies." Journal for the Scientific Study of Religion 42:43-56.

Hill, Terrence D., Amy M. Burdette, Christopher G. Ellison, and Marc A. Musick. 2006. "Religious Attendance and the Health Behaviors of Texas Adults." Preventative Medicine 42:309-12.

Huppert, Felicia A. 2009. "Psychological Well-being: Evidence Regarding Its Causes and Consequences." Applied Psychology: Health and Well-Being 1: 137-64.

Iannaccone, Laurence R. 1988. "A Formal Model of Church and Sect." American Journal of Sociology 94:S241-68.

Keister, Lisa A. 2008. "Conservative Protestants and Wealth: How Religion Perpetuates Asset Poverty." American Journal of Sociology 113:1237-71.

Keyes, Corey L. M. 2005. “Mental Illness and/or Mental Health? Investing Axioms of the Complete State
Model of Health." Journal of Consulting and Clinical Psychology 73:539-48.

Keyes, Corey L. M., Dov Shmotkin, and Carol D. Ryff. 2002. “Optimizing Well-being: The Empirical Encounter of Two Traditions." Journal of Personality and Social Psychology 82:1007-22.

King, Michael and Walter E. Schafer. 1992. "Religiosity and Perceived Stress: A Community Survey." Sociological Analysis 53:37-47.

Koenig, Harold G. 2009. "Research on Religion, Spirituality, and Mental Health: A Review." Canadian Journal of Psychiatry 54:283-91.

Koenig, Harold G., Michael E. McCollough, and David B. Larson. 2001. Handbook of Religion and Health. New York: Oxford University Press.

Krause, Neal, Christopher G. Ellison, Benjamin A. Shaw, John P. Marcum, and Jason D. Boardman. 2001. "Church-based Social Support and Religious Coping." Journal for the Scientific Study of Religion 40:637-56.

Lim, Chaeyoon and Robert D. Putnam. 2010. "Religion, Social Networks, and Life Satisfaction." American Sociological Review 75:914-33.

Lyubomirsky, Sonja, Kennon M. Sheldon, and David Schkade. 2005. "Pursuing Happiness: The Architecture of Sustainable Change." Review of General Psychology 9:111-31.

Marsden, George M. 1991. Understanding Fundamentalism and Evangelicalism. Grand Rapids, MI: William B. Eerdmans Publishing Company.

Maselko, Joanna and Laura D. Kubzansky. 2006. “Gender Differences in Religious Practice, Spiritual Experiences and Health: Results from the US General Social Survey." Social Science \& Medicine 62:2848-60.

McFarland, Michael J. 2010. "Religion and Mental Health among Older Adults: Do the Effects of Religious Involvement Vary by Gender?" Journal of Gerontology: Social Sciences 65B:621-30.

McIntosh, William Alex, Dianne Sykes, and Karen S. Kubena. 2002. "Religion and Community among the Elderly: The Relationship between the Religious and Secular Characteristics of Their Social Networks." Review of Religious Research 44:109-25.

Mirowsky, John and Catherine E. Ross. 2003. Social Causes of Psychological Distress. 2nd ed. New York: Walter de Gruyter.

Mitchell, Carey Usher and Mark LaGory. 2002. "Social Capital and Mental Distress in an Impoverished Community." City \& Community 1:195-216.

Nooney, Jennifer and Eric Woodrum. 2002. "Religious Coping and Church-based Social Support as Predic- 
tors of Mental Health Outcomes: Testing a Conceptual Model." Journal for the Scientific Study of Religion 41:359-68.

Payton, Andrew R. 2009. "Mental Health, Mental Illness, and Psychological Distress: Same Continuum or Distinct Phenomena?" Journal of Health and Social Behavior 50:213-27.

Pearce, Michelle J. and Harold G. Koenig. 2010. “Religion and Mental Health." Pp. 1449-52 in The Corsini Encyclopedia of Psychology. 4th ed., edited by I. B. Weiner and W. E. Craighead. New York: John Wiley \& Sons.

Pearlin, Leonard I. 1989. "The Sociological Study of Stress." Journal of Health and Social Behavior 30: 241-56.

Pearlin, Leonard I., Elizabeth G. Menaghan, Morton A. Lieberman, and Joseph T. Mullan. 1981. "The Stress Process." Journal of Health and Social Behavior 22: 337-56.

Perreira, Krista M., Natalia Deeb-Sossa, Kathleen Harris Mullan, and Kenneth A. Bollen. 2005. "What Are We Measuring? An Evaluation of the CES-D across Race/Ethnicity and Immigrant Generation." Social Forces 83:1567-601.

Pescosolido, Bernice A., and Sharon Georgianna. 1989. "Durkheim, Suicide, and Religion: Toward a Network Theory of Suicide." American Sociological Review 54:33-48.

Pollner, Melvin. 1989. “Divine Relations, Social Relations, and Well-being." Journal of Health and Social Behavior 39:92-104.

Presser, Stanley and Mark Chaves. 2007. "Is Religious Service Attendance Declining?" Journal for the Scientific Study of Religion 46:417-23.

Pyle, Ralph E. 2006. “Trends in Religious Stratification: Have Religious Group Socioeconomic Distinctions Declined in Recent Decades?" Sociology of Religion 67:61-79.

Radloff, Lenore S. 1977. “The CES-D Scale: A Self-report Depression Scale for Research in the General Population." Applied Psychological Measurement 1:385-401.

Riddle, Andrea S., Marc R. Blais, and Ursula Hess. 2002. "A Multi-group Investigation of the CES-D's Measurement Structure across Adolescents, Young Adults, and Middle Aged Adults." Scientific Series, CIRANO, Quebec. Retrieved March 14, 2012; http:// www.cirano.qc.ca/pdf/publication/2002 s-36.pdf

Ross, Catherine E. and Jaya Sastry. 1999. “The Sense of Personal Control: Social-structural Causes and Emotional Consequences." Pp. 369-94 in Handbook of the Sociology of Mental Health, edited by C. S. Aneshensel and J. C. Phelan. New York: Springer.
Ryff, Carol D., Gayle Dienberg Love, Heather Urry, Daniel Muller, Melissa A. Rosenkranz, Elliot M. Friedman, Richard J. Davidson, and Burton Singer. 2006. "Psychological Well-being and Ill-being: Do They Have Distinct or Mirrored Biological Correlates?" Psychotherapy and Psychosomatics 75:85-95.

Scheitle, Christopher P. and Amy Adamczyk. 2009. "It Takes Two: The Interplay of Individual and Group Theology on Social Embeddedness." Journal for the Scientific Study of Religion 48:16-29.

Schieman, Scott. 2008. "The Education-contingent Association between Religiosity and Health: The Differential Effects of Self-esteem and the Sense of Mastery." Journal for the Scientific Study of Religion 47:710-24.

Schieman, Scott, Kim Nguyen, and Diana Elliott. 2003. "Religiosity, Socioeconomic Status, and the Sense of Mastery." Social Psychology Quarterly 66: 202-21.

Schieman, Scott, Tetyana Pudrovska, Leonard I. Pearlin, and Christopher G. Ellison. 2006. "The Sense of Divine Control and Psychological Distress: Variations across Race and Socioeconomic Status." Journal for the Scientific Study of Religion 45: 529-49.

Schwadel, Philip. 2009. "Neighbors in the Pews: Social Status Diversity in Religious Congregations." Interdisciplinary Journal of Research on Religion 5:Article 2. Retrieved March 14, 2012; http://www.religjournal. com

Schwadel, Philip. 2010. "Age, Period, and Cohort Effects on U.S. Religious Service Attendance: The Declining Impact of Sex, Southern Residence, and Catholic Affiliation." Sociology of Religion 71:2-24.

Sherkat, Darren E. 2010. "Religion and Verbal Ability." Social Science Research 39:2-13.

Smidt, Corwin, ed. 2003. Religion as Social Capital: Producing the Common Good. Waco, TX: Baylor University Press.

Steensland, Brian, Jerry Z. Park, Mark D. Regnerus., Lynn D. Robinson, W. Bradford Wilcox, and Robert D. Woodberry. 2000. "The Measure of American Religion: Toward Improving the State of the Art." Social Forces 79:291-318.

Tabak, Melanie A. and Kristin D. Mickelson. 2009. "Religious Service Attendance and Distress: The Moderating Role of Stressful Life Events and Race/Ethnicity." Sociology of Religion 70:49-64.

Turner, R. Jay and J. Blake Turner. 1999. "Social Integration and Support." Pp. 301-19 in Handbook of the Sociology of Mental Health, edited by C. S. Aneshensel and J. C. Phelan. New York: Kluwer Academic/Plenum Publishers. 
Vaillant, George, Janice Templeton, Monika Ardelt, and Stephanie E. Meyer. 2008. “The Natural History of Male Mental Health: Health and Religious Involvement." Social Science \& Medicine 66:221-31.

Vilchinsky, Noa and Shlomo Kravetz. 2005. “How Are Religious Belief and Behavior Good for You? An Investigation of Mediators Relating Religion to Mental Health in a Sample of Israeli Jewish Students." Journal for the Scientific Study of Religion 44:459-71.

White, Richard H. 1968. "Toward a Theory of Religious Influence." The Pacific Sociological Review 11: 23-8.

Wilkins, Amy C. 2008. "'Happier than Non-Christians': Collective Emotions and Symbolic Boundaries among Evangelical Christians." Social Psychology Quarterly 71:281-301.
Williams, Rhys H. 2003. "The Language of God in the City of Man: Religious Discourse and Public Politics in America." Pp. 171-89 in Religion as Social Capital: Producing the Common Good, edited by C. Smidt. Waco, TX: Baylor University Press.

Woolever, Cynthia and Deborah Bruce. 2002. A Field Guide to U.S. Congregations: Who's Going Where and Why. Louisville, KY: Westminster John Knox Press.

Wuthnow, Robert. 2002. "Religious Involvement and Status-bridging Social Capital." Journal for the Scientific Study of Religion 41:669-84. 